\title{
Promoting InNOVATION BY WOMEN THROUGH ENGINEERING ENTREPRENEURSHIP COURSES: AN ASSESSMENT OF ENTREPRENEURIAL SELF-EFFICACY
}

\author{
Prateek Shekhar ${ }^{l}$, Anastasia Ostrawoski ${ }^{l}$, Aileen-Huang Saad ${ }^{1}$, and Julie Libarkin ${ }^{2}$ \\ ${ }^{1}$ Department of Biomedical Engineering, University of Michigan, Ann Arbor, MI, USA \\ ${ }^{2}$ Department of Geological Sciences, Michigan State University, East Lansing, MI, USA \\ Corresponding Author: aileenhs@umich.edu
}

\begin{abstract}
Engineering entrepreneurship education programs are increasingly exposing students to entrepreneurship and innovation. Little is known about student learning gains in these programs, particularly from a gender perspective. This study examines gender differences in students' Entrepreneurial Self-efficacy (ESE) among students enrolled in a senior-level College of Engineering's entrepreneurship practicum course. The ESE Scale was administered at the beginning and end of the semester to measure students' self-efficacy for five ESE constructs - searching, planning, marshalling, implementing-people and implementing-finance. The findings reveal improvement in students searching, planning, marshalling, and implementing-finance constructs after the course. Significant gender differences were found for planning, marshalling, and implementingfinance constructs in students' pre survey responses with female students reporting lower ESE. However, no significant gender differences were noted in students' post survey responses. This indicates that female students were able to reach similar levels of ESE as male students as an outcome of instruction. These results demonstrate the positive impact of an entrepreneurship course on female students' ESE and the importance of entrepreneurship programs for promoting innovation regardless of gender.
\end{abstract}

Keywords: entrepreneurship, engineering education, self-efficacy, innovation, gender.

\section{INTRODUCTION}

Recently, researchers and national reports have called for promoting innovation in engineering undergraduates [1], [2]. Consequently, significant growth in engineering and technology specific entrepreneurship programs has taken place [3] with the aim to prepare students for an increasingly competitive global market [4]. As of 2010, $50 \%$ of ASEE affiliated schools offered entrepreneurship education to engineering students [5]. Continued promotion of entrepreneurship and innovation [6] through programs such as the National Science Foundation (NSF) funded Epicenter Program: National Center for Engineering Pathways to Innovation and NSF I-Corps [3], and Kern Entrepreneurial Engineering Network [7] has likely increased the number of programs offered to engineering students. Engineering entrepreneurship programs expose students to entrepreneurial practices such as developing business models, performing customer-discovery, and participating in pitch competitions [8] through an unique combination of courses, active learning pedagogies, and co-curricular programming [4], [9]-[11]. For example, students in these courses might work towards developing a mobile app in a team-based project-learning environment by identifying problems, performing customer discovery, developing a business model and participating in pitch competitions to gain funding.

In addition to imparting business knowledge, these entrepreneurship programs place emphasis on fostering innovation among engineering undergraduates [8], [11], [12] to develop a diverse, innovative workforce [3]. As a result, these programs have emerged as a platform to teach innovation to engineering students from various sub-disciplines including but not limited to electrical engineering, computer science, and computer engineering. However, studies assessing the student learning outcomes of these programs are not common. Furthermore, those studies that do exist have been conducted from a genderneutral perspective [13]. Though the participation of women in entrepreneurial ventures has increased [14][16], women face different obstacles than male entrepreneurs [17]-[19].

Research examining the effectiveness of entrepreneurship education has placed little emphasis on gender interactions. Further research is necessary to understand the complexities of the engineering entrepreneurship environment and the role of individual characteristics on entrepreneurial success with respect to 
gender. Through the use of McGee's validated Entrepreneurial Self-Efficacy scale [20], this study seeks to understand gender differences in ESE in an engineering entrepreneurship course.

Gender has been noted as a factor leading to differences in individuals' ESE [21], [22]. Female students been shown to have lower ESE than male counterparts [22], [23], suggesting that gender plays an important mediating role in different entrepreneurship outcomes and these influences are often complex and warrant further research. To fill this gap in literature, this study answers the following research question: How do students' Entrepreneurial Self-Efficacy change in engineering entrepreneurship courses and how do these changes differ between men and women?

\section{LITERATURE REVIEW}

\subsection{Entrepreneurial Self-Efficacy}

Self-efficacy is an individual's evaluation of their abilities to "mobilize the motivation, cognitive resources, and courses of action needed to exercise control over events in their lives" [24] (p. 364). Several researchers have demonstrated that self-efficacy is an important factor in predicting individual's performance [24]-[28]. In other words, individuals with high self-efficacy in completing a particular task are highly likely to demonstrate high performance in the task. This general concept of selfefficacy is mapped to Entrepreneurial Self-Efficacy (ESE) in entrepreneurship research and is described as one's self-perception of his/her skills and abilities to successfully perform different entrepreneurial roles and tasks [21]-[23].

ESE is becoming an important metric for assessing the outcome of entrepreneurship programs because it has been shown to be an important influencer of entrepreneurial intentions [21], [23], [29]. Particularly for females, researchers have reported a direct relationship between entrepreneurial self-efficacy and entrepreneurial intentions in young female students [30]. In addition, researchers have also highlighted the importance of ESE in predicting creative and entrepreneurial behavior [31], [32]. Due to these critical influences, ESE is commonly used to evaluate entrepreneurial success in entrepreneurship education research [21]-[23], [33]-[39].

It is important to note that gender differences in ESE have been reported in the literature [21], [22], [30]. For instance, in their examination of undergraduate and graduate business students, Chowdhury \& Endres [40] found that women have lower entrepreneurial selfefficacy than men. In another study, MBA program alumni and adolescents' entrepreneurial self-efficacy and entrepreneurial intention scores were compared across genders [22]. Researchers found that women exhibited lower entrepreneurial self-efficacy and entrepreneurial self-intention scores than men for both participant groups. In a similar examination, Urban [41] demonstrated that ESE and some of its constructs (management, innovation, marketing, financial, and risk) are influenced by gender. In their study of higher education management students, they found that women scored higher in the innovation and marketing constructs then men and scored generally higher overall. Gender differences for the other constructs were not found to be significant [41], underscoring the importance of examining general ESE and also it subconstructs across gender.

In summary, the research attention given to ESE in existing entrepreneurship-related literature suggests that it is an important outcome that should be examined when assessing entrepreneurship education programs. Also, prior work shows students' gender may also impact their ESE leading to differences between men and women's learning outcomes. However, these prior studies have mostly been conducted in business fields, mostly because entrepreneurship is in a nascent stage in engineering when compared to business. Thus, there is need to research gender differences in students' ESE in engineering entrepreneurship courses.

\subsection{Barriers to Women in Entrepreneurship}

Researchers have focused on identifying reasons behind low participation of women in entrepreneurship. In its current state, entrepreneurship is often perceived as challenging by women due to their lack of confidence in performing different entrepreneurial tasks or lower ESE. Lim and Envick's [42] examined differences across gender in university students and reported lower confidence in risk-taking in women when compared to men as a probable reason for lower orientations toward entrepreneurship. In another study, Menzies and Tatroff [43] reported lower confidence pertaining to risk-taking in women as female students viewed entrepreneurship as a field that 'wouldn't fit their personality'. Similarly, in Marlino and Wilson's [44] study, young girls described entrepreneurship as 'hard, complicated, and risky', demonstrating a lack of confidence in entering entrepreneurship.

In addition to risk-taking, researchers have noted that women tend to have lower confidence in other entrepreneurship-related areas. For example, researchers have noted that women do not believe they possess the knowledge necessary for entrepreneurship [30], [45], [46]. Also, they hold negative perceptions of career success in entrepreneurship [47] and hold fear of failure [38], hindering their participation [47]. 
One of the factors leading to women's lower confidence in succeeding in entrepreneurship can be attributed to entrepreneurship being a male dominated field. The lack of women role models and entrepreneurs may negatively impact women's confidence or ESE and discourage them from engaging in entrepreneurship education [48]. Echoing societal gender norms, Cañizares and Garcia [49] found that men felt a greater affinity for initiative, creativity, optimism, and self-confidence traits than women. Specifically regarding confidence, Kepler and Shane [50] and Brown [51] analyzed the differences in traits between female and male entrepreneurs and found that female entrepreneurs exhibited lower confidence levels in their entrepreneurial abilities than males.

In summary, women's confidence in performing different entrepreneurship-related tasks due to negative self-perceptions are detrimental to their engagement in entrepreneurship. Thus, it is important to examine these self-perceptions or ESE in the context of engineering entrepreneurship education. As explicated in the previous section, more empirical work examining gender differences in ESE in students engaged in engineering entrepreneurship programs is needed. Findings of such work can help in providing insights on how to tailor entrepreneurship education curriculum to address entrepreneurial self-efficacy gender differences and consequently improve entrepreneurship intentions in women [21], [22], [30], [41], [45], [47], [52]-[55]. Guided by this need for additional research, the presented work investigates gender differences in students' changes in Entrepreneurial Self Efficacy (ESE) in an entrepreneurship practicum course. The study examines if exposure to entrepreneurial practices through engineering entrepreneurship course leads to improvement in students' ESE, particularly for women who as suggested in the literature tend to have lower ESE than men.

\section{METHODOLOGY}

This study was conducted over three semesters of a three-credit, senior level entrepreneurship practicum course offered through the College of Engineering at a large research university located in the United States. Leveraging the Business Model Canvas [56] and Lean Launch Curriculum [57], the course exposed students to various entrepreneurial experiences such as customer discovery [57], [58] and product validation [57] in a project-based learning environment. Students worked in teams to complete multiple projects throughout the semester. These projects placed emphasis on revenue generation, identifying opportunities, transforming the idea into business plan, and performing validation of proposed business plan. Students were encouraged to use a variety of on and off-campus resources to create a profitable product or service. The classes met for one 120minute session per week over the semester.

A pre-validated Entrepreneurship Self-Efficacy (ESE) Scale developed by McGee et. al. [39] was used in this study. The ESE assessment consisted of 19 Likert-Scale items examining 5 sub-constructs of ESE: (1) searching, (2) planning, (3) marshaling, (4) implementing-people, and (5) implementing-financial [39]. The searching dimension focuses on the development and/or identification of an idea or opportunity. The planning dimension focuses on activities, which transform the idea or opportunity into a business plan. The marshaling dimension includes organizing resources to launch a business venture. The implementing phase is divided into two dimensions: implementing-people and implementingfinance. Implementing-people focuses on people aspects of sustaining the venture, while implementing-finance focuses on the financial aspects of sustaining the venture.

Following a pre-post research design, the survey was administered at the beginning and end of the semester over three course offerings (Winter/Spring 2016, Fall 2016, and Winter/Spring 2017). The course offerings were divided into three sections taught by three different instructors (two men and one woman). Instructors met as a teaching team to ensure consistency of content across sections and terms. The total enrolment for the three course offerings was 216 undergraduate students; a total of 196 students participated in the study. After excluding missing responses, 172 student responses were collected from 61 woman self-identified students and 111 man selfidentified students (response rate $=80 \%$ ). Data analysis was performed using SPSS version 24 statistical software. First, a confirmatory factor analysis was performed on the data set to assure validity of the survey, a recommended practice when using a pre-validated survey [39], [59]. High Cronbach's Alpha values for the five constructs demonstrated the internal consistently of the scale -0.79 (Searching), 0.74 (Planning), 0.80 (Marshaling), 0.94 (Implementing-People), and 0.91 (ImplementingFinance). After confirming the reliability of the survey items with respect to their associated constructs, scores for the five constructs were calculated by averaging individual responses to the relevant survey items. Descriptive statistics were used to examine overall students' pre/post responses. A mixed ANOVA was performed to investigate significant interaction effects between students' pre/post responses and gender. If there was a significant interaction, a univariate ANOVA was conducted to further examine gender differences in students' pre and post responses. Findings of these analyses are presented in the next section. 


\section{RESULTS}

\subsection{Descriptive Statistics}

Overall, this study found differences in men and women students' pre and post responses, with men achieving higher mean scores in each of the five ESE constructs. Before the course, women and men mean scores were most separated (mean difference $=0.60$ ) for the Implementing-Finance construct, suggesting stronger self-efficacy for men in handling the financial aspects of venture creation process. The smallest difference between women and men's scores was 0.13 in the ImplementingPeople construct.

This pre score difference between men and women decreased at the end of the semester. In the post responses, women and men's scores were most separated for the Searching construct with a difference of 0.18 between scores with the male students scoring higher. This suggests that even at the end of a course experience, men have stronger self-efficacy related to searching for a venture. The smallest score difference between men and women was the Implementing-Finance construct with a difference of 0.016 with women scoring higher than men. Implementing-Finance is the only construct where women's' scores were higher than men's' scores. This suggests that women were able to increase their selfefficacy related the financial aspects of a implementing a venture throughout the course resulting in stronger selfefficacy in this area than men.

Thus, the results demonstrate that ESE improved for men and women after participating in the course. Particularly, for students who are women, these improvements were highest for searching, planning and implementing finance, with post-pre differences of 0.64 , 0.82 and 0.86 respectively. The full descriptive statistics of students' pre and post responses for men and women are presented in Table 1.

\subsection{Mixed ANOVA Analysis}

The statistical significance of these interactions was examined using a Mixed ANOVA to provide insight into changes between pre and post responses for men and women. Gender, the independent variable, was analyzed to determine if a significant interaction existed for the various ESE constructs with survey response (pre vs. post), the dependent variable. While descriptive statistics

Table 2: Mixed ANOVA results for time (pre and post)

\begin{tabular}{llll}
\hline \hline \multicolumn{1}{c}{ Construct } & F & Sig & Partial $\boldsymbol{\eta}^{2}$ \\
\hline Searching & 48.94 & $<0.05$ & 0.22 \\
Planning & 56.57 & $<0.05$ & 0.25 \\
Marshaling & 22.51 & $<0.05$ & 0.12 \\
Implementing-People & 1.79 & 0.18 & 0.01 \\
Implementing- & 23.39 & $<0.05$ & 0.12 \\
Finance & & & \\
\hline \hline
\end{tabular}

TABLE 1: Descriptive statistics for students' pre and post responses $(n=111$ (men) and 61 (women))

\begin{tabular}{|c|c|c|c|}
\hline Construct & Gender & Mean & SD \\
\hline \multicolumn{4}{|l|}{ Searching } \\
\hline \multirow[t]{3}{*}{ Pre } & Women & 3.27 & 0.71 \\
\hline & Men & 3.66 & 0.75 \\
\hline & Total & 3.52 & 0.76 \\
\hline \multirow[t]{3}{*}{ Post } & Women & 3.91 & 0.71 \\
\hline & Men & 4.09 & 0.62 \\
\hline & Total & 4.02 & 0.66 \\
\hline \multicolumn{4}{|l|}{ Planning } \\
\hline \multirow[t]{3}{*}{ Pre } & Women & 2.87 & 0.70 \\
\hline & Men & 3.24 & 0.76 \\
\hline & Total & 3.11 & 0.76 \\
\hline \multirow[t]{3}{*}{ Post } & Women & 3.68 & 0.79 \\
\hline & Men & 3.71 & 0.77 \\
\hline & Total & 3.70 & 0.77 \\
\hline \multicolumn{4}{|l|}{ Marshaling } \\
\hline \multirow[t]{3}{*}{ Pre } & Women & 3.49 & 0.79 \\
\hline & Men & 3.87 & 0.72 \\
\hline & Total & 3.74 & 0.77 \\
\hline \multirow[t]{3}{*}{ Post } & Women & 4.06 & 0.76 \\
\hline & Men & 4.10 & 0.70 \\
\hline & Total & 4.08 & 0.72 \\
\hline \multicolumn{4}{|c|}{ Implementing - People } \\
\hline \multirow[t]{3}{*}{ Pre } & Women & 3.68 & 0.81 \\
\hline & Men & 3.81 & 0.75 \\
\hline & Total & 3.77 & 0.77 \\
\hline \multirow[t]{3}{*}{ Post } & Women & 3.79 & 0.93 \\
\hline & Men & 3.94 & 0.71 \\
\hline & Total & 3.88 & 0.79 \\
\hline \multicolumn{4}{|c|}{ Implementing - Finance } \\
\hline \multirow[t]{3}{*}{ Pre } & Women & 2.61 & 1.04 \\
\hline & Men & 3.23 & 1.07 \\
\hline & Total & 3.01 & 1.10 \\
\hline \multirow[t]{3}{*}{ Post } & Women & 3.48 & 0.96 \\
\hline & Men & 3.46 & 1.03 \\
\hline & Total & 3.47 & 1.00 \\
\hline
\end{tabular}

showed overall increase in post responses across all five constructs irrespective of student gender, statistically significant differences were found only for four constructs: searching, planning, marshaling, and implementing-finance (Table 2).

For Searching, there was a statistically significant difference in mean between the pre and post survey response $\left(\mathrm{F}(1,170), \mathrm{p}=<0.05\right.$, partial $\left.\eta^{2}=0.22\right)$. Similarly, for Planning, $\mathrm{F}(1,170)=56.57, \mathrm{p}=<0.05$, partial $\eta^{2}=0.25$; for Marshaling, $\mathrm{F}(1,169)=22.51, \mathrm{p}=<$ 0.05 , partial $\eta^{2}=0.12$; and, for Implementing-Finance, $\mathrm{F}(1,168)=23.39, \mathrm{p}=<0.05$, partial $\eta^{2}=0.12$. This shows that overall students ESE significantly increased from the beginning of the course (pre) to the end of the course (post) for the four of the five constructs.

To examine differences between male and female students, this study explored the interaction between gender (men and women) and survey response (pre and post). There are statistically significant interactions for only three ESE constructs: Planning $(\mathrm{F}(1,170)=4.00, \mathrm{p}=$ 
0.05 , partial $\left.\eta^{2}=0.02\right)$, Marshaling $(\mathrm{F}(1,169)=4.06, \mathrm{p}=$ 0.045 , partial $\eta^{2}=0.02$ ), and Implementing-Finance $\left(F(1,168)=7.76, p=0.006\right.$, partial $\left.\eta^{2}=0.04\right)$. It is worth noting that in contrast with planning and marshaling, implementing-finance had the greatest significant ( $\mathrm{p}<$ 0.01 ) suggesting the largest interaction effect of gender was found in implementing-finance construct. There was no statistically significant interaction between gender (men and women) and survey response (pre and post) on Searching $\left(F(1,170)=1.82, p=0.180\right.$, partial $\left.\eta^{2}=0.01\right)$ and Implementing-People $(\mathrm{F}(1,169)=0.012, \mathrm{p}=0.92$, partial $\eta^{2}=<0.05$ ) (Table 3).

Thus, while there were significant differences between pre and post survey response for four ESE constructs (searching, planning, marshaling and implementing finance), interaction effects of gender were found significant in only three constructs (planning, marshaling, and implementing-finance). While Searching was statistically significant between pre and post survey response, it was not significant with relation to gender. The Implementing-People construct had no statistically significant relationships between either pre and post survey response or gender, suggesting it was not impacted by either gender or survey response.

Statistically significant interactions were found between gender (men and woman) and survey response (pre and post). These results suggest that gender significantly interacts with survey response for these three constructs. All of these constructs demonstrate significant differences between pre and post survey response as discussed above and significant differences for gender. Further analysis was conducted to understand the impacts of survey response and gender on the significant interactions.
TABLE 3: Multivariate results for interaction between gender and time (pre and post)

\begin{tabular}{llll}
\hline \multicolumn{1}{c}{ Construct } & \multicolumn{3}{c}{ Interaction } \\
\hline & F & Sig & Partial $\eta^{2}$ \\
\hline Searching & 1.82 & 0.18 & 0.011 \\
Planning & 4.00 & 0.047 & 0.023 \\
Marshaling & 4.06 & 0.045 & 0.023 \\
Implementing-People & 0.012 & 0.92 & $<0.05$ \\
$\begin{array}{l}\text { Implementing- } \\
\text { Finance }\end{array}$ & 7.76 & 0.006 & 0.044 \\
\hline \hline
\end{tabular}

\subsection{Univariate Analysis of Variance}

Further analysis was conducted for the three statistically significant interactions to investigate which survey response (pre or post) differed significantly across gender. Univariate Analysis of Variance was completed for the Planning, Marshaling, and Implementing-Finance constructs (see Table 4 for results). For the Planning construct, there was a significant difference between genders (men and women) for the pre survey response $\left(\mathrm{F}(1,195)=4.16, \mathrm{p}=0.043\right.$, partial $\left.\eta^{2}=0.021\right)$, suggesting gender differences with respect to the Planning construct at the beginning of the course. There was not a significant difference between genders (men and women) for the post survey response $(\mathrm{F}(1,170)=0.041, \mathrm{p}=0.84$, partial $\left.\eta^{2}=<0.05\right)$, suggesting that women could not be distinguished from men based on the Planning construct of ESE. For the Marshaling construct, there was a significant difference between genders (men and women) for the pre survey response $(\mathrm{F}(1,194)=7.418, \mathrm{p}=0.007$, partial $\eta^{2}=0.037$ ), suggesting gender differences for the ESE construct at the beginning of the course. There was no significant difference between genders (men and women) for the post survey response $(\mathrm{F}(1,170)=0.095$, $\mathrm{p}$ $=0.76$, partial $\left.\eta^{2}=0.001\right)$, suggesting that women could

TABLE 4: Univariate analysis of variance

\begin{tabular}{|c|c|c|c|c|c|c|}
\hline Construct & & Mean & SD & $\overline{\mathbf{F}}$ & Sig & Partial $\eta^{2}$ \\
\hline \multicolumn{7}{|l|}{ Planning } \\
\hline \multirow[t]{2}{*}{ Pre } & Women & 2.94 & 0.089 & \multirow{2}{*}{4.16} & \multirow{2}{*}{0.043} & \multirow{2}{*}{0.021} \\
\hline & Men & 3.17 & 0.068 & & & \\
\hline \multirow[t]{2}{*}{ Post } & Women & 3.68 & 0.099 & \multirow{2}{*}{0.041} & \multirow{2}{*}{0.84} & \multirow{2}{*}{$<0.05$} \\
\hline & Men & 3.71 & 0.074 & & & \\
\hline \multicolumn{7}{|l|}{ Marshaling } \\
\hline \multirow[t]{2}{*}{ Pre } & Women & 3.53 & 0.89 & \multirow{2}{*}{7.42} & \multirow{2}{*}{0.007} & \multirow{2}{*}{0.037} \\
\hline & Men & 3.84 & 0.058 & & & \\
\hline \multirow[t]{2}{*}{ Post } & Women & 4.06 & 0.093 & \multirow{2}{*}{0.095} & \multirow{2}{*}{0.76} & \multirow{2}{*}{0.001} \\
\hline & Men & 4.09 & 0.069 & & & \\
\hline \multicolumn{7}{|c|}{ Implementing Finance } \\
\hline \multirow[t]{2}{*}{ Pre } & Women & 2.66 & 0.121 & \multirow{2}{*}{12.71} & \multirow{2}{*}{$<0.05$} & \multirow{2}{*}{0.062} \\
\hline & Men & 3.20 & 0.092 & & & \\
\hline \multirow[t]{2}{*}{ Post } & Women & 3.48 & 0.128 & \multirow{2}{*}{0.010} & \multirow{2}{*}{0.92} & \multirow{2}{*}{$<0.05$} \\
\hline & Men & 3.46 & 0.095 & & & \\
\hline
\end{tabular}


not be distinguished from men based on the Marshaling construct of ESE at the end of the course. For the Implementing-Finance construct, there was a significant difference between genders (men and women) for the pre survey response $\left(\mathrm{F}(1,193)=12.71, \mathrm{p}=<0.05\right.$, partial $\eta^{2}=$ 0.062 ), suggesting men and women differences in this construct. There was no significant difference between genders (men and women) for the post survey response $\left(\mathrm{F}(1,170)=0.01, \mathrm{p}=0.92\right.$, partial $\left.\eta^{2}=<0.05\right)$, suggesting that women could not be distinguished from men based on the Implementing-Finance construct of ESE at the end of the course. The post survey results for all three constructs discussed here are not significant with relation to gender. This demonstrates an improvement of female score between the pre and post survey. While gender differences in mean scores were present in the pre survey, female scores improved over the course to become indistinguishable to the male scores of the post survey, suggesting that the entrepreneurship course assisted in improving female ESE scores for the Planning, Marshaling, and Implementing-Finance constructs.

\section{DISCUSSION AND CONCLUSION}

These findings demonstrate that students' ESE increased at the end of the engineering entrepreneurship course. Apart from implementing people, there was a statistically significant difference in mean scores for all other constructs (searching, planning, marshaling, and implementing finance) between pre and post responses. This indicates that students' entrepreneurial self-efficacy pertaining to the searching, planning, marshaling and implementing-finance constructs were significantly higher at the end of the semester when compared to the their pre responses.

Gender appeared to be important for only three constructs, with statistically significant interactions between gender (men and women) and course exposure (pre and post) on planning, marshaling, and implementing-finance. This showed that there were significant differences in male and female students' pre/post responses for these three ESE constructs. Further univariate analysis of variances for these three constructs showed that the interaction effects were significant due to significant differences in the pre scores between male and female students. These results show that female students overall reported lower ESE. This is consistent with prior work that has shown that men generally have higher ESE than women [30], [36], [55], [60]-[62].

In addition, the study examines differences in various ESE sub-constructs between men and women. Particularly, the results show that for planning, marshaling and implementing finance, female students exhibited lower self-efficacy in the beginning of the course when compared to male students. Overall, there are not many studies that have examined construct-level differences in ESE between men and women. Of the very few studies, Urban et al [41], reported that women scored higher in innovation and marketing constructs, with all other ESE constructs being insignificant. This is different from the findings reported in this paper, which showed that women held lower ESE for different constructs than men. One plausible explanation for this difference is the difference in the population studied. In contrast to the undergraduate students participating in our presented study, Urban et al. examined a MBA student population, which is highly likely to have experience working in business environments and feel confident about skills related to innovativeness and marketing. This contrast reiterates that engineering educators and researchers should be cognizant of not blindly using the research in business fields to evaluate and design engineering entrepreneurship programs. Nevertheless, although these constructs do not overlap with the measures used in the presented study, they resonate with the finding that men and women may differ in their ESE for the different constructs being measured.

Lastly, one major finding is that after exposure to the engineering entrepreneurship course, both male and female students scored equally on the three constructs that they reported lower at the beginning of the semester. Thus, at the end of the course, female students were able to reach similar levels of ESE as male students. In other words, the course was able to positively impact women's ESE. For example, although the pre score differences were highest for implementing finance construct, there were no significant differences in the post scores between male and female students. One plausible explanation could be that the course projects that placed emphasis on revenue generation allowed students with learning experiences that enhanced their implementing finance ESE. On a broader level, these findings highlight that the choice of content and pedagogy will have a varied impact on different targeted entrepreneurial learning outcomes. Current engineering entrepreneurship programs fall under a wide range of curricular and co-curricular approaches. Future work should focus of assessing different curricular and pedagogical approaches in their effectiveness to meet the desired learning outcomes.

In summary, the importance of innovation and entrepreneurship in undergraduate engineering education is becoming well established. In contrast, best practices in innovation and entrepreneurship are in their nascent state and have yet to be well established. This study begins to unpack the importance of thoughtfully constructing innovation and entrepreneurship experiences for higher education. Particularly, how these experiences 
impact learning outcomes among a diverse group of students. The results of this work demonstrate that entrepreneurship education does influence student entrepreneurial self-efficacy. It also shows that while women have a lower self-efficacy before participating in an entrepreneurship course, their entrepreneurial selfefficacy reaches similar levels to their male colleagues after participating in the course. Also, it shows that female students tend to have lower ESE for some constructs than others. With this knowledge and awareness, program administrators can enact more targeted approaches in entrepreneurship education to support female students in areas that they might find challenging. These results continue to demonstrate the importance of formal entrepreneurial curriculum for women to ensure that entrepreneurship education programs continue to graduate diverse [63], innovative and entrepreneurial students. However, further research needs to be conducted to strengthen the applicability of the findings in other scenarios. Since the study was limited to one large public institution, researchers can conduct similar studies at different institution types (e.g. public/private or based on Carnegie classification). Also, similar assessment in different engineering entrepreneurship programs will help in identification of best ways for fostering innovation (e.g. formal coursework or informal co-curricular programs). Furthermore, future studies can conduct similar examination across students based on their ethnicity and socio-economic backgrounds. A more thorough understanding of these differences and similarities will assist in better designing new engineering entrepreneurship programs and improvise the existing ones that are still in the stages of infancy to increase their effectiveness in achieving their targeted goals and outcomes.

\section{Acknowledgements}

This project is funded by the U.S. National Science Foundation through grant numbers 1504257 and 1531533. The opinions are those of the authors and do not necessarily represent the National Science Foundation.

\section{References}

[1] National Academy of Engineering, The Engineer of 2020: Visions of Engineering in the New Century. Washington, DC: National Academy of Engineering, 2004.

[2] D. T. Rover, "New economy, new engineer," J. Eng. Educ., vol. 94, no. 4, pp. 427-428, 2005.

[3] C. S. Morton, A. Huang-Saad, and J. Libarkin, "Entrepreneurship education for women in engineering: a systematic review of entrepreneurship assessment literature with a focus on gender," in ASEE Annual Conference and Exposition, 2016.

[4] A. Huang-Saad, C. S. Morton, and J. Libarkin, "Unpacking the impact of engineering entrepreneurship education that leverages the Lean LaunchPad curriculum," in IEEE Frontiers in Education Conference, 2016.

[5] A. Shartrand, P. Weilerstein, M. Besterfield-Sacre, and K. Golding, "Technology entrepreneurship programs in U.S. engineering schools: course and program characteristics at the undergraduate level," in American Society for Engineering Education, 2010.

[6] N. E. Council and C. of E. A. \& O. of S. and T. Policy, "A Strategy for American Innovation.” 2011.

[7] KEEN, "Kern Entrepreneurial Engineering Network," 2017. .

[8] N. Duval-Couetil, A. Shartrand, and T. Reed, "The role of entrepreneurship program models and experiential activities on engineering student outcomes," Adv. Eng. Educ., vol. 5, no. 1, pp. 1-27, 2016.

[9] S. Celis and A. Huang-Saad, "Students seeking different paths to entrepreneurial education," in ASEE Annual Conference and Exposition, 2015.

[10] N. Duval-Couetil, A. Shartrand, and T. Reed-Rhoads, "The role of entrepreneurship program models and experiential activities on engineering student outcomes," Adv. Eng. Educ., vol. 5, no. 1, pp. 1-27, 2016.

[11] S. Gilmartin, A. Shartrand, H. Chen, C. Estrada, and S. Sheppard, "U.S. based entrepreneurship programs for undergraduate engineers." 2014.

[12] T. Standish-Kuon and M. P. Rice, "Introducing engineering and science students to entrepreneurship: Models and influential factors at six American universities," J. Eng. Educ., vol. 91, no. 1, p. 33, 2002.

[13] C. S. Morton, A. Y. Huang-Saad, and J. C. Libarkin, "Entrepreneurship education for women in engineering: A systemic review of entrepreneurship assessment literature with a focus on gender," in ASEE 123rd Annual Conference, 2016.

[14] V. Estes, "Women and business development: promoting economic growth and job creation." USAID/Europe and Eurasia Bureau, 1999.

[15] S. E. Jalbert, "Women entrepreneurs in the global economy." Washington DC: Center for International Private Enterprise, 2000.

[16] "Woman-owned businesses." Washington DC: The Center for Women's Business Research, 2004.

[17] R. Chaganti and P. G. Greene, "Who are ethnic entrepreneurs?: a study of entrepreneurs' ethnic involvement and business characteristics," J. Small Bus. Manag., vol. 40, no. 2, pp. 126-143, 2002.

[18] P. G. Greene, M. M. Hart, E. J. Gatewood, C. G. Brush, and N. M. Carter, "Women entrepreneurs: moving front and center," Coleman White Pap. Ser., vol. 3, pp. 1-47, 2003.

[19] L. K. Gundry and H. P. Welsch, "The ambitious entrepreneur: high growth strategies of women-owned enterprise," J. Bus. Ventur., vol. 16, no. 5, pp. 453-470, 2001. 
[20] J. E. McGee, M. Peterson, and S. L. Mueller, "Entrepreneurial self-efficacy: refining the measure," Entrep. Theory Pract., pp. 965-988, 2009.

[21] H. Zhao, C. Seibert, and C. Hills, "The mediating role of selfefficacy in the development of entrepreneurial intentions," $J$. Appl. Psychol., vol. 90, no. 2, pp. 1265-1272, 2005.

[22] F. Wilson, J. Kickul, and D. Marlino, "Gender, entrepreneurial self-efficacy, and entrepreneurial career intentions: implications for entrepreneurship education," Entrep. Theory Pract., pp. 387-406, 2007.

[23] C. Chen, P. Greene, and A. Crick, "Does entrepreneurial selfefficacy distinguish entrepreneurs from managers?," J. Bus. Ventur., vol. 13, pp. 295-316, 1998.

[24] R. Wood and A. Bandura, "Social cognitive theory of organizational management," Acad. Manag. Rev., vol. 14, pp. 361-384, 1989.

[25] A. Bandura, "Self-efficacy: Toward a unifying theory of behavioral change," Psychol. Rev., vol. 84, pp. 91-215, 1977.

[26] A. Bandura, "Self-efficacy mechanism in human agency," Am. Psychol., vol. 37, pp. 122-147, 1982.

[27] A. Bandura, Social foundations of thought and action: A social cognitive theory. Englewood Cliffs, N.J: Prentice-Hall, 1986.

[28] A. Bandura and D. H. Schunk, "Calculating competence, selfefficacy and intrinsic interest through proximal selfmotivation," J. Pers. Soc. Psychol., vol. 41, pp. 586-598, 1981.

[29] F. Linan and Y. W. Chen, "Development and cross-cultural application of a specific instrument to measure entrepreneurial intentions," Entrep. Theory Pract., vol. 33, no. 3, pp. 593-617, 2009.

[30] J. Kickul, F. Wilson, D. Marlino, and S. Barbosa, "Are misalignments of perceptions and self-efficacy causing gender gaps in entrepreneurial intentions among our nations teens?," J. Small Bus. Enterp. Dev., vol. 15, no. 2, pp. 321-335, 2008

[31] A. Bandura, C. Barbaranelli, G. Caprara, and C. Pastorelli, "Self-efficacy beliefs as shapers of children's aspirations and career trajectories," Child Dev., vol. 72, no. 1, pp. 187-206, 2001.

[32] A. Bandura, Self-efficacy: The exercise of control. New York, NY: Freeman \& Co., 1997.

[33] N. Boyd and G. Vozikis, "The influence of self-efficacy on the develompent of entrepreneurial intentions and actions," Entrep. Theory Pract., pp. 63-77, 1994.

[34] A. R. Englehart, "Traditional versus nontraditional industries: exploring the effect of entrepreneurial efficacy on women business owners," in Annual Academy of Management, Entrepreneurship Division, 1995.

[35] N. F. Krueger Jr. and D. V Brazeal, "Entrepreneurial potential and potential entrepreneurs," Entrep. Theory Pract., pp. 91104, 1994.

[36] R. F. Scherer, J. S. Adams, S. S. Carley, and F. A. Wiebe, "Role model performance effects on development of entrepreneurial career preference," Entrep. Theory Pract., vol.
13, pp. 53-71, 1989.

[37] S. Barbosa, M. Gerhardt, and J. Kickul, "The role of cognitive style and risk preference on entrepreneurial self-efficacy and entrepreneurial intentions," J. Leadersh. Organ. Stud., vol. 13, no. 4, pp. 86-104, 2007.

[38] B. Bird, "Implementing entrepreneurial ideas: the case for intention," Acad. Manag. Rev., vol. 13, no. 3, pp. 442-453, 1988.

[39] J. E. Mcgee, M. Peterson, S. L. Mueller, and J. M. Sequeira, "Entrepreneurial self-efficacy: Refining the measure," Entrep. Theory Pract., vol. 33, no. 4, pp. 965-988, 2009.

[40] S. Chowdhury and M. Endres, "Gender differences and the formation of entrepreneurial self-efficacy," in United States Association of Small Business (USASBE) Annual Conference, 2005.

[41] B. Urban, "A gender perspective on career preferences and entrepreneurial self-efficacy," in International Council for Small Business World Conference, 2011.

[42] S. Lim and B. R. Envick, "Gender and entrepreneurial orientation: a multi-country study," Int. Entrep. Manag. J., vol. 9, no. 3, pp. 465-482, 2013.

[43] M. Menzies and H. Tatroff, "The propensity of male vs. female students to take courses and degree concentrations in entrepreneurship," J. Small Bus. Entrep., vol. 19, no. 2, pp. 203-223, 2006

[44] D. Marlino and F. Wilson, "Teen girls on business: Are they being empowered?," Simmons School of Management and The Committee of 200, Boston, MA, USA, 2003.

[45] M. L. Kourilsky and W. Walstad, "Entrepreneurship and female youth: Knowledge, attitudes, gender differences, and educational practices," J. Bus. Ventur., vol. 13, no. 1, pp. 7788, 1998.

[46] K. Jones and R. Tullous, "Behaviors of pre-venture entrepreneurs and perceptinos of their financial needs," $J$. Small Bus. Manag., vol. 40, pp. 233-249, 2002.

[47] R. S. Shinnar, O. Giacomin, and F. Janssen, "Entrepreneurial perceptions and intentions: The role of gender and culture," Entrep. Theory Pract., vol. 36, pp. 465-493, 2014.

[48] P. Ulvenblad, M. Blomkvist, and A. Hansson, "World-class entrepreneurship and innovation programmes in sweeden Focus on gender perceptions," in International Council for Small Buisness World Conference Proceedings, 2011.

[49] S. M. Sanchez Canizares and F. J. Fuentes Garcia, "Gender differences in entrepreneurial attitudes," Equal. Divers. Incl. An Int. J., vol. 29, no. 8, pp. 766-786, 2010.

[50] E. Kepler and S. Shane, "Are male and femal entrepreneurs really that different?" Small Business Administration, Office of Advocacy, 2007.

[51] W. Brown, "Ambition versus action: Do males and females exhibit conflicting perspectives of entrepreneurial potential and growth? A study among entrepreneurship students and entrepreneurship graduates before and after start-up," in Institute for Small Business and Entrepreneurship National Small Firms Policy and Research Conference: Competing 
Perspectives of Small Business and Entrepreneurship, 2002.

[52] J. Florin, R. Karri, and N. Rossiter, "Fostering entrepreneurial drive in business education: An attitudinal approach," $J$. Manag. Educ., vol. 31, no. 1, pp. 17-42, 2007.

[53] S. L. Mueller and S. Goic, "East-West differences in entrepreneurial self-efficacy: implications for entrepreneurship education in transition economies," Int. J. Entrep. Educ., vol. 1, no. 4, pp. 613-632, 2003.

[54] L. Cox, S. Mueller, and S. Moss, "The impact of entrepreneurship education on entrepreneurial self-efficacy," Int. J. Entrep. Educ., vol. 1, no. 2, 2002.

[55] C. Baughn, J. Cao, L. Le, V. Lim, and K. Neupert, "Normative, social and cognitive predictors of entrepreneurial interest in China, Vietnam and the Philippines," J. Dev. Entrep., vol. 11, no. 1, pp. 57-77, 2006.

[56] A. Osterwalder and Y. Pigneur, "Business model generation." 2010.

[57] S. Blank and B. Dorf, "The startup owner's manual: the stepby-step guide for building a great cocmpany." 2012.

[58] S. G. Blank, The four steps to epiphany, 1 st. San Francisco: K \& S Ranch, 2003.

[59] P. M. Kreiser, L. D. Marino, and K. M. Weaver, “Assessing the psychometric properties of the entrepreneurial orientation scale: a multi-country analysis," Entrep. Theory Pract., vol. 26, no. 4, pp. 71-94, 2002.

[60] A. De Noble, D. Jung, and S. Ehrlich, "Entrepreneurial self efficacy: The development of a measure and its relationship to entrepreneurial action," in Frontiers of Entrepreneurship Research, 1999, pp. 73-87.

[61] J. Kickul and R. D'Intino, "Measure for measure: modeling entrepreneurial self-efficacy onto instrumental tasks within the new venture creation process," in United States Association for Small Business and Entrepreneurship Conference, 2004.

[62] S. L. Mueller and M. C. Dato-on, "Gender-role orientation as a determinant of entrepreneurial self-efficacy," J. Dev. Entrep., vol. 13, no. 1, pp. 3-20, 2008.

[63] A. Huang-Saad and S. Celis, "How student characteristics shape engineering pathways to entrepreneurship education," Int. J. Eng. Educ., vol. 33, no. 2, pp. 527-537, 2017. 